\title{
Organizational Culture, Job Satisfaction and Organizational Citizenship Behavior in Employees
}

\author{
Pradipta Windaru \\ Faculty of Psychology, Gunadarma University \\ E-mail : pradiptawindaru@gmail.com
}

\begin{abstract}
A growing organization can be seen from the organizational culture and job satisfaction where employees work. These aspects are included in the behavior of employees who support the organization voluntarily and sincerely which is known as organizational citizenship behavior (OCB). The purpose of this study was to determine empirically whether organizational culture and job satisfaction affect employee OCB. This study involved 110 employees. Multiple Regression is used to test the hypothesis in this study. The result of this study indicates that organizational culture and job satisfaction affect $O C B$ with a contribution of $29.6 \%$.
\end{abstract}

Published by IJRP.ORG. Selection and/or peer-review under responsibility of International Journal of Research Publications (IJRP.ORG)

Keywords : organizational culture, job satisfaction, organizational citizenship behavior, employees.

\section{Introduction}

Human resources are important in an organization because the success of the organization is highly dependent on the quality and performance of the individuals in the organization (Darmawati, Hidayati \& Herlina, 2013).

Every organization wants employees who are willing to contribute more than their job. Every employee who exceeds the mandatory role and does not expect a reward for the organization, this is better known as organizational citizenship behavior (OCB) (Organ, 1997).

Robbins (2006) states that organizational citizenship behavior is behavior that is not a formal obligation of organizational members, but this behavior supports organizational functions effectively. Employees who are more supportive of organizational functions as well as their colleagues will have an 
OCB attitude and a good mood will likely be involved in OCB (Robbins \& Judge, 2013).

According to Organ (in MacKenzie, Podsakoff \& Fetter, 1993) OCB has a wide range including altruism, courtesy, civic virtue, sportsmanship, and conscientiousness. Altruism is thoughtful behavior that has the effect of helping others. Courtesy is behavior that prevents problems from occurring or alleviates work-related problems. Civic virtue is responsible behavior, care about organization, initiative. Sportsmanship is willingness, without complaining and tolerance. Conscientiousness is thoughtful behavior that transcends organizational boundaries and roles.

Bachrach. et al (2000) suggest several characteristics that influence OCB, including individual characteristics, work, organization, and organizational leadership. One of its characteristics is organizational characteristic that supports the existence and positive self-development of employees through organizational culture, as well as an appropriate reward system, where employees will show OCB behavior as a form of reciprocity for what employees give. In this case, organizational culture becomes a characteristic that can influence OCB behavior in employees. The role of culture in influencing employee behavior seems to be increasingly important in today's workplace, the shared meaning provided by a strong culture ensures that all employees are directed in the same direction, and increases the consistency of employee behavior (Robbins, 2006).

Organizational culture according to Cameron and Quinn (2011) is the main distinguishing feature between one company and another, competitive advantage and the most powerful factor in the company that becomes the asset in the company's success. Organizational culture has a strong effect on organizational development and effectiveness.

Miharty (2013) defines that organizational culture refers to the basic assumption patterns shared and groups which have been able to solve problems adopted from external and internal integration that have worked well enough to be considered. The main function of organizational culture is as a differentiating boundary against the environment, organizations and other groups as well as a control mechanism in guiding and shaping employee attitudes and behavior (Supartha \& Sintaasih, 2008).

Organizational culture is able to have a positive impact on OCB in a company. Oemar (2013) states that the more positive employees are in assessing organizational culture and the more involved they are in organizations in their institutions, the tendency for OCB will increase as well.

According to Organ, MacKenzie and Podsakoff, (2006) organizational culture is able to create a unique environment to associate and describe employee behavior or sacrifice that transcends roles with employee satisfaction and loyalty to the company's vision and mission.

Job satisfaction according to Spector (1997) is defined in simple terms how a person feels about his 
job and the different aspects of the job, which one he likes (satisfied) or dislikes (dissatisfied). Locke (1976) defines job satisfaction as a positive emotional level and pleases the individual.

Employees who are satisfied with their work according to Organ and Ryan (in Luthans, 2006) will participate more in $\mathrm{OCB}$, for example working voluntarily for extra work activities, helping colleagues, and making positive comments about the company.

Based on the explanation previously described, the hypotheses that can be developed in this study are (1) H1 organizational culture can explain the occurrence of OCB in employees; (2) H2 job satisfaction can explain the occurrence of OCB in employees; and (3) H3 organizational culture and job satisfaction can explain the occurrence of OCB in employees.

\section{Research Method}

This study involved 110 employees. The answer choices on each scale range from 1 to 5 ranging from Strongly Disagree to Strongly Agree.

Organizational culture according to Denison (1996) is the values, beliefs and principles that serve as the basis for an organizational management system, as well as practices and behavior management that help and strengthen these basic principles. In this research, organizational culture will be adapted based on the dimensions compiled by Fey and Denison (2003), consisting of 36 items with 4 dimensions, each dimension consisting of 3 indicators, namely: 1) Engagement (Empowerment, Team orientation, and Capability development), 2) Consistency (Core values, Agreement, and Coordination and integration), 3) Adaptability (Creating change, Customer focus, and Organizational learning), and 4) Mission (Strategic direction and intent, Goals and objectives, and Vision).

One item on this scale is "This company has a number of clear and consistent values that guide me to work." After collecting the data, the reliability result on the Organizational Culture scale was 0.935 with 4 items dropping out of 36 items.

Job satisfaction described by Herzberg (1959) is how a person feels about work and its aspects. In this study, job satisfaction will be adapted based on the dimensions compiled by Herzberg (1959), consisting of 31 items with 6 dimensions: Achievement, Recognition, The work itself, Responsible, Advancement, Possibility of growth.

One of the items on this scale is "Are you satisfied with your current assignment?" After collecting the data, the reliability result on the Job Satisfaction scale was 0.954 with no items dropping out of the 31 items.

Organ (1988) in his book defines OCB as the behavior of workers or employees who exceed the 
requirements of the job indirectly and explicitly recognized by the reward system because it supports organizational functions. In this study the OCB scale was adapted from Kumari and Shah (2015) based on the development of Podsakoff, et. all consisting of 15 items with 5 forms of OCB, namely altruism, courtesy, civic virtue, sportsmanship, and conscientiousness.

One item on this scale is "I am willing to help colleagues when they have problems at work." After collecting data, the reliability result on the OCB scale was 0.807 with 1 item dropping out of 15 items.

The data processing technique in this study used multiple regression.

\section{Result and Discussion}

Based on the research, the table below explains the results of the regression test for each variable as follows:

Table 1. Regression Test

\begin{tabular}{|c|c|c|c|c|c|}
\hline \multirow[t]{2}{*}{ Variable $\mathrm{X}$} & \multicolumn{2}{|c|}{ Unstandardized Coefficients } & \multirow{2}{*}{$\begin{array}{c}\begin{array}{c}\text { Standardized } \\
\text { Coefficients }\end{array} \\
\beta\end{array}$} & \multirow[t]{2}{*}{$\mathbf{t}$} & \multirow[t]{2}{*}{ Sig. } \\
\hline & B & Std. Error & & & \\
\hline Organizational culture & -.051 & .045 & -.123 & -1.128 & .262 \\
\hline Job satisfaction & .202 & .036 & .618 & 5.674 & .000 \\
\hline
\end{tabular}

Variable Y : OCB

Based on Table 1, that organizational culture does not have a significant effect on OCB with a value of 0.262 , the result of this study is in line with Warsito (2008). While job satisfaction has a significant effect on OCB of 0.000 , this result is in line with Rahman (2014), namely that job satisfaction affects OCB as well as Nafi and Indrawati's (2017) research, namely that job satisfaction is positively correlated with OCB. Based on the results of statistical tests, H1 which reads organizational culture can explain the occurrence of OCB in employees, is not proven.

The results of this study indicate that organizational culture has no influence on OCB that involvement, consistency, ability, and mission have no role in helping co-workers' behavior. As many as 46 employees in this study have a working period of less than 1 year, this certainly affects the adaptation process so that implementation in the culture in the company is not fully attached to employees so that it has an impact on positive and voluntary behavior to support the organization known as OCB. According to Hofstede (2001) that organizational culture consists of basic assumptions and individual responses to resolving adaptation problems in the work environment or organization.

Meanwhile the result of the statistical test in Table 1 shows that the job satisfaction variable has a positive and significant effect on $\mathrm{OCB}$, therefore $\mathrm{H} 2$ which says job satisfaction can explain the occurrence of OCB in employees, is proven. 
The results of this study indicate that increased job satisfaction causes OCB to increase, this is in line with research conducted by Salehi and Goltash (2011). This can be seen from the perception of job satisfaction related to feelings of pleasure in several main aspects of work which received positive responses that will be a driving factor for the stronger OCB. Research by Ristiana (2013) states that job satisfaction is an important determinant that encourages someone to show OCB behavior, because employees who get satisfaction in their work will tend to interpret the work and tasks they carry out responsibly and with dedication. This is also in line with the theory of Robbins (2006) which states that satisfied employees tend to speak positively about the organization, help other employees and are able to work beyond normal expectations at work.

Table 2. Multiple Regression Test Result

\begin{tabular}{ll}
\hline R Square & .296 \\
\hline Uji F & 22.502 \\
\hline Sig. & .000 \\
\hline
\end{tabular}

Based on Table 2, it can be seen that the influence of the independent variables on the dependent variable is (R Square) 29.6\%, the rest is another factor outside the research. Judging from the $\mathrm{F}$ test of 22,502 with a significance of 0.000 , it means that shared organizational culture and job satisfaction have an effect on the OCB variable because it has a significance of $0.000(\alpha<0.05)$. Then $\mathrm{H} 3$ organizational culture and job satisfaction can explain the occurrence of OCB in employees, it is proven.

This is in line with Mahardika and Wibawa's research (2019) that employees who implement and understand organizational culture well and have job satisfaction will improve OCB behavior among employees in companies and organizations. In addition, supported by Husodo's research (2018) maintaining a culture of mutual assistance between divisions if there is a division that is in need of assistance, this makes members of each division have the awareness to help their colleagues, especially new colleagues in learning about their new job.

\section{Conclusion}

Based on the research result, it can be concluded that organizational culture has no influence on OCB. Further, job satisfaction has an influence on OCB. However, only if at the same time organizational culture and job satisfaction have an influence on OCB in employees.

\section{Suggestion}

Based on the result of the research, the following suggestion can be given to employees who are 
expected to understand and improve OCB behavior in the organization where they work so that the organizational culture that is implemented will be better which makes employees satisfied at work, there is a sense of comfort and content in the office.

\section{Reference}

Bachrach, D. G. Et al. 2000. Organizational citizenship behavior : A critical review of the theoritical and empirical literature and suggestions for future research. Journal of Management, 26, 513-563.

Cameron, K. S. dan Quinn, R. E. (2011). Diagnosing and changing organizational culture: based on the competing values framework ed.3rd. San Francisco: Jossey-Bass.

Darmawati, A., dkk. (2013). Pengaruh Kepuasan Kerja dan Komitmen Organisasi terhadap Organizational Citizenship Behavior. Jurnal Economia. Vol. 9 No. 1

Denison, D. R. (1996). Corporat culture and organizational effectiveness. Canada: John Wiley \& Sons.

Fey, C. F., \& Denison, R. D. (2003). Organizational culture and effectiveness : Can American theory be applied in Rusia?. Organization Science, 14 (6), 686-706

Herzberg, F., et.al. (1959). The Motivation to Work (2nd ed.). USA: Wiley International Edition.

Hofstede, G. (2001). Cultures Consequences 2nd : Comparing Values, Behaviors, Institutions, and Organizations Across Nations. California: SAGE

Husodo, Y. R. P. (2018). Pengaruh Budaya Organisasi Terhadap Organizational Citizenship Behavior (OCB) dengan Kepuasan Kerja Sebagai Variabel Intervening Pada PT Jatim Indo Lestari. AGORA. 6 (1). 1-8

Kumari, M. M., \& Shah, S. A. (2015). Psychometric properties of Podsakoff's organizational citizenship behaviour scale in the Asian context. The International Journal of Indian Psychology, 3(1), 51-60.

Locke. E. A. (1976). The Nature and Cause of Job Satisfaction in Handbook of Industrial and Organizational Psychology (Ed MD Dunette). Chicago: Rand Mc Narlly.

Luthans, F., Vogelgesang, G., R., \& Lester, P., B. (2006). Developing the psychological capital of resiliency. Human Resource Development Review, 5 (1), 25-44.

MacKenzie, S. B., Podsakoff, P. M., \& Fetter, R. (1993). The impact of organizational citizenship behavior on evaluations of salesperson performance. Journal of Marketing, 57(1), 70-80.

Mahardika, I. N. B. P. \& Wibawa, I. M. A. (2019). Pengaruh Budaya Organisasi Kepuasan Kerja dan Komitmen Organisasional Terhadap Organizational Citizenship Behavior Pada Karyawan. EJurnal Manajemen. 8 (1). 7340- 7370.

Miharty. (2013). "The Influence of Organizational Culture on Job Satisfaction towards Improving the Quality of Education in University of Riau". Asian Social Science. 9 (12). 60-68

Nafi, C. \& Indrawati, E. S. (2017). Hubungan Antara Kepuasan Kerja Dengan Organizational Citizenship Behavior Pada Karyawan CV. Elfa's Kudus. Jurnal Empati. 7 (3). 134-145

Oemar, Y. (2013). Pengaruh Budaya Organisasi, Kemampuan Kerja dan Komitmen Organisasi terhadap Organizational Citizenhsip Behavior (OCB) Pegawai pada BAPPEDA Kota Pekanbaru. Jurnal Aplikasi Manajemen. 11(1). 65-76

Organ, D. W. (1988). Organizational citizenship behavior: the good soldier syndrome. England : Lexington Books.

Organ, D. W., MacKenzie, S. B., \& Podsakoff, P. M. (2006). Organizational Citizenship Behavior Its Nature, Antecedents, and Consequences. SAGE Publications: USA.

Organ, D.W. (1997). Organizational citizenship behaviour : it's construct clean-up time. Human Performance, $10(2), 85-97$.

Rahman, U. (2014). Kepuasan Kerja dan Organizational Citizenship Behavior Pada Guru Madrasah Aliyah Madani Alauddin Paopao Gowa Sulawesi Selatan. Jurnal Analisa. 21 (1). 131-142 
Ristana, M. (2013). Pengaruh Komitmen Organisasi Dan Kepuasan Kerja Terhadap Organizational Citizenship Behavior (OCB) Dan Kinerja Karyawan Rumah Sakit Bhayangkara Trijata Denpasar. Jurnal Ilmu Ekonomi \& Manajemen. 9 (1). 56-70

Robbins, S. P. \& Judge, T.A. (2013). Organizational behaviour ed. 15th. Pearson : New York.

Robbins, S. P. (2006). Perilaku Organisasi. Edisi Kesepuluh. Jakarta: PT. Indeks Kelompok Gramedia.

Spector, P. E. (1997). Job Satisfaction. California: SAGE

Supartha, W. G. \& Sintaasih, D. K. (2017). Pengantar Perilaku Organisasi : Teori, Kasus dan Aplikasi Penelitian. Denpasar Timur: CV Setia Bakti

Warsito, B. (2008). Pengaruh Budaya Organisasi dan Lingkungan Kerja Terhadap Organizational Citizenship Behavior, Motivasi dan Kinerja (Survey Pada Karyawan Hotel Berbintang di Kota Malang dan Batu). Jurnal Ekonomi Modernisasi. 4 (2). 83-96 